\title{
Seed position and influences on Caesalpinia pulcherrima germination and reserve proteins
}

Patrick Luan Ferreira dos Santos ${ }^{1}$, Regina Maria Monteiro de Castilho ${ }^{2}$, Raquel Reia Pinheiro ${ }^{3}$

\begin{abstract}
Caesalpinia pulcherrima has diverse uses in the world, including ornamental and landscape characteristics, but there is a great disparity of germination during the time of seedlings production, being this factor attributed to the position of the seeds in fruits. This study aimed to evaluate some germinative aspects and concentration of reserve proteins in C. pulcherrima seeds in the function of its position in fruits. The work was carried out in greenhouse, in a completely random experimental design, with five seed position in the pod, based on the distance from seed to the peduncle (P1 - distal, P2 - distal/median, P3 - median, P4 -proximal/ median, P5 - proximal). Eight replicates with eight seeds each, were sowed to germinate for 21 days in expanded polystyrene trays filled with substrate. The percentage, speed index, average germination time and $50 \%$ germination time of the plantlets were evaluated. The reserve proteins (albumin, globulin, prolamin and glutelin) contents were also determined. There was influence of the position of the seed in the fruit on germination and reserve proteins contents. The proximal/median position showed excellent results, having correlations of albumin, globulin and glutelin concentrations with some germinative parameters. Therefore, the use of proximal/median position of the seeds is recommended for $C$. pulcherrima propagation.
\end{abstract}

Keywords: germinative aspects, seed vigor, propagation, paradise flower.

\section{Resumo}

\section{Posição de sementes e influencia na germinação e proteínas de reserva em Caesalpinia pulcherrima}

Caesalpinia pulcherrima apresenta diversos usos no mundo, mas há grande disparidade de germinação no momento da produção de mudas, sendo esse fator talvez atribuído à posição que a semente ocupa no fruto. Assim, o objetivo deste trabalho foi avaliar aspectos germinativos e concentrações de proteínas de reserva em sementes de $C$. pulcherrima em função de sua posição no fruto. $\mathrm{O}$ trabalho foi conduzido em casa de vegetação, em delineamento inteiramente casualizado, com cinco tratamentos de posição da semente na vagem, com base na distância da semente ao pedúnculo (P1-distal, P2-distal/mediana, P3-mediana, P4-proximal/ mediana, P5-proximal). Sendo oito repetições, com oito sementes por repetição, que foram colocados para germinar durante 21 dias em bandejas de poliestireno expandido cheios de substrato. Foram avaliados a porcentagem, índice de velocidade e tempo médio de germinação e germinação de $50 \%$ da população. Ainda em laboratório, foi determinado o conteúdo das proteínas de reserva (albumina, globulina, prolamina e glutelina). Os resultados foram submetidos à análise de variância e teste de tukey e determinado o coeficiente de correlação. Houve influência da posição da semente sobre o fruto na germinação e nas proteínas de reserva de $C$. pulcherrima, onde a posição proximal/mediana apresentou excelentes resultados, tendo correlações das frações albumina, globulina e glutelina com alguns parâmetros germinativos, sendo então o uso de sementes da posição proximal/mediana é recomendado para a propagação da espécie.

Palavras-chave: aspectos germinativos, vigor de sementes, propagação de espécies, flor-do-paraíso

\section{Introduction}

Caesalpinia pulcherrima (L.) SW. is a tree-shrub species belonging to the family Fabaceae (subfamily: Caesalpinioideae), originating in Central America, popularly known as wonder or paradise flower (Flora do Brasil, 2018). The species can be used as hedges, windbreaks, landscape projects and the afforestation of cities, due to their diversity of colors and small size
(Oliveira et al., 2010). In Asian countries China and India, this plant is used on local medicine to treat a number of diseases, such as bronchitis, diabetes and malaria infection (Moteriya and Chanda, 2016).

However, despite of having so many applications, C. pulcherrima does not have sufficient information to subsidize large-scale seedling production (Araújo et al., 2014), since there are few studies involving the morphometric characteristics of fruits and seeds, or

\footnotetext{
${ }^{1}$ Universidade Estadual Paulista, Departamento de Solos e Recursos Ambientais, Faculdade de Ciências Agronômicas, Botucatu-SP, Brazil. "Corresponding author: patricklfsantos@gmail.com

${ }^{2}$ Universidade Estadual Paulista, Departamento de Fitotecnia, Tecnologia de Alimentos e Sócio economia, Campus de Ilha Solteira, Ilha Solteira-SP, Brazil. ${ }^{3}$ Universidade Federal de São Carlos, Centro de Ciências Biológicas e da Saúde, São Carlos-São Paulo, Brazil. 
information which can be used in germination tests (Araújo Neto et al., 2014). Thus, some seed propagation studies of the species have begun to emerge in recent years (Alves et al., 2017). However, according to Oliveira et al. (2010) there is a great lack of germination of the species at the time of production of seedlings. This factor may be attributed to the position of the seed in the fruit (Mendonça et al., 2016), which may be associated with different maturation stages.

According to Rocha et al. (2017) the seeds of the family Fabaceae can present different sizes, depending on their position in the pod, which end up influencing the emergence of the same. Furthermore, there may be variations in the contents of the reserve proteins, which are the main factors responsible for germination (Taiz and Zeiger, 2017). Albumin and globulin are mainly stored in the embryo, serving as the main reserve source at the time of germination processes, already prolamin and glutelin were found in large proportions in the endosperm (Nonogaki et al., 2007). Thus, these proteins are of extreme importance for the germination of the seeds, existing then a relationship among seed position in the fruit, protein content and germinative processes. This issue, although discussed since the 1960, is rarely the subject of scientific studies (Mendonça et al., 2016).

Studies with forest species that evaluate the effect of the position of the seed on the fruit on the germination occur with Enterolobium contortisiliquum (Lessa et al., 2014), Caesalpinia ferrea (Nogueira et al., 2010), Bauhinia ungulate (Mena-Ali and Rocha, 2005) and with Mimosa caesalpiniifolia (Freitas et al., 2013). Thus, the objective of this work was to evaluate the germination and concentrations of the reserve proteins in Caesalpinia pulcherrima seeds in the function of their fruit position.

\section{Material and methods}

The experiment was carried out in a greenhouse $(\mathrm{Pad} \&$ Fan - Average temperature $28.94{ }^{\circ} \mathrm{C}$ and $57.72 \%$ Average Relative Humidity) in Ilha Solteira, São Paulo State, Brazil. According to the Köppen classification, the climate of the region is Aw, characterized by a rainy season in the summer and dry in the winter, defined as humid tropical, with an annual average temperature of $25.1^{\circ} \mathrm{C}$ and average annual rainfall of $1,335 \mathrm{~mm}$ with average relative humidity year of 64.8\% (Santos and Hernandez, 2013).

Fruits of $C$. pulcherrima was collected in the city of Ilha Solteira, on March 3, 2012, and subsequently dried in the shade for 7 days. With the seeds removed and grouped according to their respective position in the fruit, based on the distance of the seed to the peduncle (Figure 1), being that pods were used that contained five seeds, and then stored in a cold room.

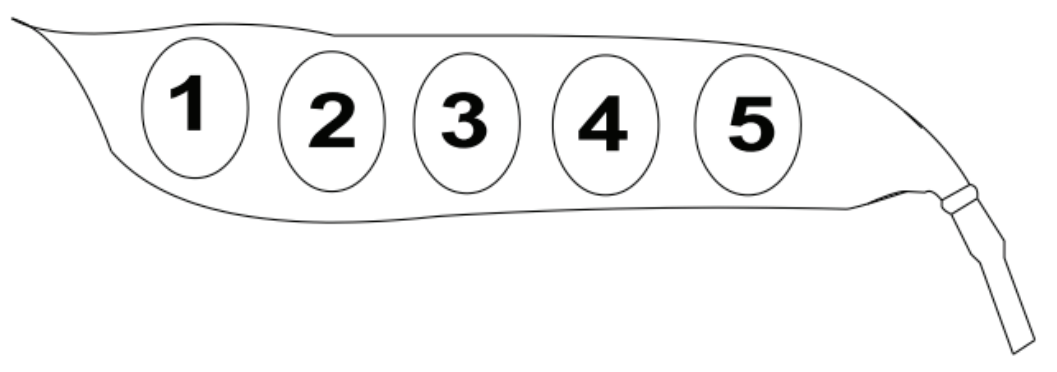

Figure 1. Position of the seed in the pod, based on the distance from the seed to the peduncle. 1-distal; 2-distal/median; 3-median; 4-proximal/median; 5-proximal.

The seeds were placed to germinate on September 22, 2012 , in expanded polystyrene tray (128 cells), in substrate composed of coconut fiber + carbonized rice hull + peat + expanded vermiculite $(1 \mathrm{v}: 1 \mathrm{v}: 1 \mathrm{v}: 1 \mathrm{v})(\mathrm{pH}=6.0$ and $\mathrm{CE}=$ $1.4 \mathrm{dSm}^{-1}$ ), which according to Santos and Castilho (2018a) is essential for the development of plants. Forming a completely random experimental design with 5 treatments [Position 1 - distal (P1); Position 2 - distal/median (P2); Position 3 - median (P3); Position 4 - proximal/median (P4); Position 5 - proximal (P5)] and 8 replications with 8 seeds per each.

The evaluations were carried out for 21 days, being considered germinated the seeds that presented seedlings with the height of the shoot of $2 \mathrm{~mm}$, and thus it was evaluated: Percentage of germination (\%); Germination speed index (GSI): calculated by formula GSI $=\Sigma$ (ni/ ti), where: $\mathrm{ni}=$ number of seeds germinating at time 'i'; ti = time after test installation (MAGUIRE, 1962);
Average germination time - AGT (days): calculated by the formula $\mathrm{AGT}=(\Sigma$ ni.ti $) /(\Sigma$ ni $)$, where: $n i=$ number of seeds germinated per day; $\mathrm{ti}=$ time after test installation (Labouriau, 1983).

Time for $50 \%$ germination of the seed population $\left(\mathrm{T}_{50}\right)$ (Coolbear et al., 1984).

Also, in a laboratory of plant physiology, was determined on September 25, 2012, from the same batch of seeds, the amount of proteins reserve of each treatment according to the methodology of Bradfort (1976), evaluating the concentrations of Albumin, Globulin, Prolamine and Glutelin.

Thus, the results were submitted through analysis of variance (ANAVA) and Tukey test at the 5\% probability level for comparison of averages, using the program "Statistix 10" for data analysis, and calculation of the correlation coefficient by Pearson, between the germinative aspects and the reserve proteins. 


\section{Results and Discussion}

It is observed that in the germination percentage results (Table 1), P4 presented the highest value (85.94\%) differing only from P1 and P2, while the lowest PG was found by P2 (54.69\%), however, results are within the range of Caesalpinia pulcherrima germination reported by Araújo Neto et al. (2014) from $47.93 \%$ to $70.47 \%$.

Table 1. Percentage of Germination (PG), Germination Speed Index (GSI), Average Germination Time (AGT) and Time to germination of $50 \%$ population $\left(\mathrm{T}_{50}\right)$ of the Caesalpinia pulcherrima in relation to the position of the seed in the fruit.

\begin{tabular}{|c|c|c|c|c|c|}
\hline \multirow{2}{*}{ Position } & PG & GSI & \multicolumn{2}{|c|}{ AGT } & \multicolumn{1}{|c|}{ T $_{\mathbf{5 0}}$} \\
\hline & $\mathbf{\%}$ & ---- & ----- days & ----- \\
\hline P1 - distal & $59.37 \mathrm{~b}$ & $0.52 \mathrm{~b}$ & $9.35 \mathrm{bc}$ & $9.18 \mathrm{a}$ \\
\hline P2 - distal-median & $54.69 \mathrm{~b}$ & $0.50 \mathrm{~b}$ & $8.75 \mathrm{bc}$ & $8.99 \mathrm{a}$ \\
\hline P3 - median & $70.31 \mathrm{ab}$ & $0.56 \mathrm{~b}$ & $10.53 \mathrm{ab}$ & $8.67 \mathrm{a}$ \\
\hline P4 - proximal-median & $85.94 \mathrm{a}$ & $0.88 \mathrm{a}$ & $8.32 \mathrm{c}$ & $8.79 \mathrm{a}$ \\
\hline P5 - proximal & $71.88 \mathrm{ab}$ & $0.59 \mathrm{~b}$ & $9.78 \mathrm{a}$ & $8.94 \mathrm{a}$ \\
\hline C.V.C. $(5 \%)$ & 21.83 & 0.20 & 1.13 & 1.90 \\
\hline CV $(\%)$ & 22.18 & 23.02 & 8.38 & 14.86 \\
\hline F & $5.14 * *$ & $9.74 * *$ & $9.82^{* *}$ & $0.18^{\text {ns }}$ \\
\hline
\end{tabular}

Averages followed by the same do not differ at the level of $5 \%$ of significance by the Tukey test. ns - not significant; * - significant at $5 \% ; * *$ - significant at $1 \%$

Already for works of the family Fabaceae, which aim germination in relation to the position of the seed in the fruit, Freitas et al. (2013) in Mimosa caesalpinifolia did not find a statistically significant difference between the different treatments of position (proximal, intermediate and distal) presenting a range ranging from $82.5 \%$ to $89.2 \%$, where in the present work only P4 is within the cited. Oliveira and Moraes (1997) noticed that the seeds of the base of the fruit of Leucena leucocephala and the apex of Prosopis juliflora showed the greatest germination.

Nogueira et al. (2010), working with Caesalpinia ferrea seeds as a function of the position in the pod, showed that the proximal position showed better germination when compared to the medial and distal ones. In the present study, position P4 was the one that presented the best results, being this proximal/median; however, this treatment did not differ from $\mathrm{P} 3$ and $\mathrm{P} 5$.

Bawa and Buckley (1989) state that the seed located closer to the peduncle of the fruit is favored in comparison to the others. Because competition occurs for nutrients, which is more intense in elongated fruits such as pods of the Fabaceae family, in which the linear arrangement of the seeds may decrease the flow of nutritional resources from one seed to another. Thus, the competition for resources, as posed by Lee and Bazzaz (1982), may favor the closest zygote, and in the present study, P4 and P5 are closer to the branch, and presented the best results (Table 1), corroborating with the aforementioned.

Mendonça et al. (2016), in a work with fruit and seed morphology and germination of Poincianella pyramidalis, state that the more distant a seed is from the fruit insertion in the branch, the less germination will occur, and was also observed that the intermediate seeds presented greater germinative power. In the present study, the same ones occur, since the more distant ones (P1 and P2), obtained the lowest values, while P3, P4 and P5 the best results.

Regarding GSI (Table 1), the values ranged from 0.50 to 0.88 , and the highest result was reached by $\mathrm{P} 4$, which differs from all other treatments. According to Santos and Castilho (2018b) seeds with high GSI values are more resistant to the adverse conditions of the medium, because they germinate faster and decrease the initial stage of development of seedling production, thus, it is expected that P4 has said characteristics. However, the results are outside the ones verified by Araújo Neto et al. (2014) in Caesalpinia pulcherrima from 1.49 to 6.9.

In germination studies with Mimosa caesalpiniifolia (Fabaceae), Freitas et al. (2013) found results of GSI ranging from 8.1 to 10.5 and did not observe a difference between the position of the seed in the fruit. The same was confirmed by Mendonça et al. (2016), where the authors did not observe significance of the position in the seed in the pod for GSI of Poincianella pyramidalis, where the results ranged from 4.38 to 5.03 .

For AGT, a range of 8.32 to 10.53 days was observed, and $\mathrm{P} 4$ presented the best result, that is, it germinated in a shorter time when compared to the other treatments. However, positions 1 and 2, which had the lowest percentage of germination and IVG, did not differ statistically from P4. It is also noted that P4 that presented the highest germination speed, consequently verified the lowest AGT. This is explained by the fact that IVG and TMG are inversely proportional, that is, if the germination speed is higher, the time the seed takes to germinate is 
lower (Santos and Castilho, 2018b). However, the results of P4 are above that observed by Souza et al. (2014) in Caesalpinia pulcherrima, 6.5-7.5 days.

The P4, possibly germinated in a shorter time, due to the greater amount of nutritional reserves present, as suggested by Menn-Ali and Rocha (2005) for Bauhinia ungulata (Fabaceae), which say that there is maternal nutrient favoring for embryos located closer to the branch. However, Paise et al. (2007) did not observe statistical difference in embryos of the basal, median and apical parts of Sophora tomentosa fruits.

It is still outstanding that there was influence of the position of the seed in the AGT, however, for the germination time of $50 \%$ of the seed population $\left(\mathrm{T}_{50}\right)$, no significant statistical difference was detected, where the results were very close (8.67 to 9.18 days). In spite of this, P3 that presented lower $\mathrm{T}_{50}$, was the treatment that presented greater AGT (10.53 days). In Figure 2, it is evident the evolution of the percentage of germination, as a function of the time of the experiment. Position 4 that presented the best results was the one that first germinated, initiating the emergency 5 days after the test installation. Positions 1 and 2 were those that had the last seeds germinated at 13 days.

Another factor that may explain the difference between the results is a physiological maturity point, which can be influenced by the position of the seed in the fruit. Lorenzetti et al. (2018) observed in Caesalpinia peltophoroides that mature seeds presented $45 \%$ of PG, being that in the present work, all are above this value, thus inferring that they are ripe. However, Silva et al. (2015) found that Caesalpinia pluviosa seeds at the physiological maturity point showed germination around $60 \%$, with P3, P4 and P5 being above that, and $\mathrm{P} 1$ and $\mathrm{P} 2$ below.

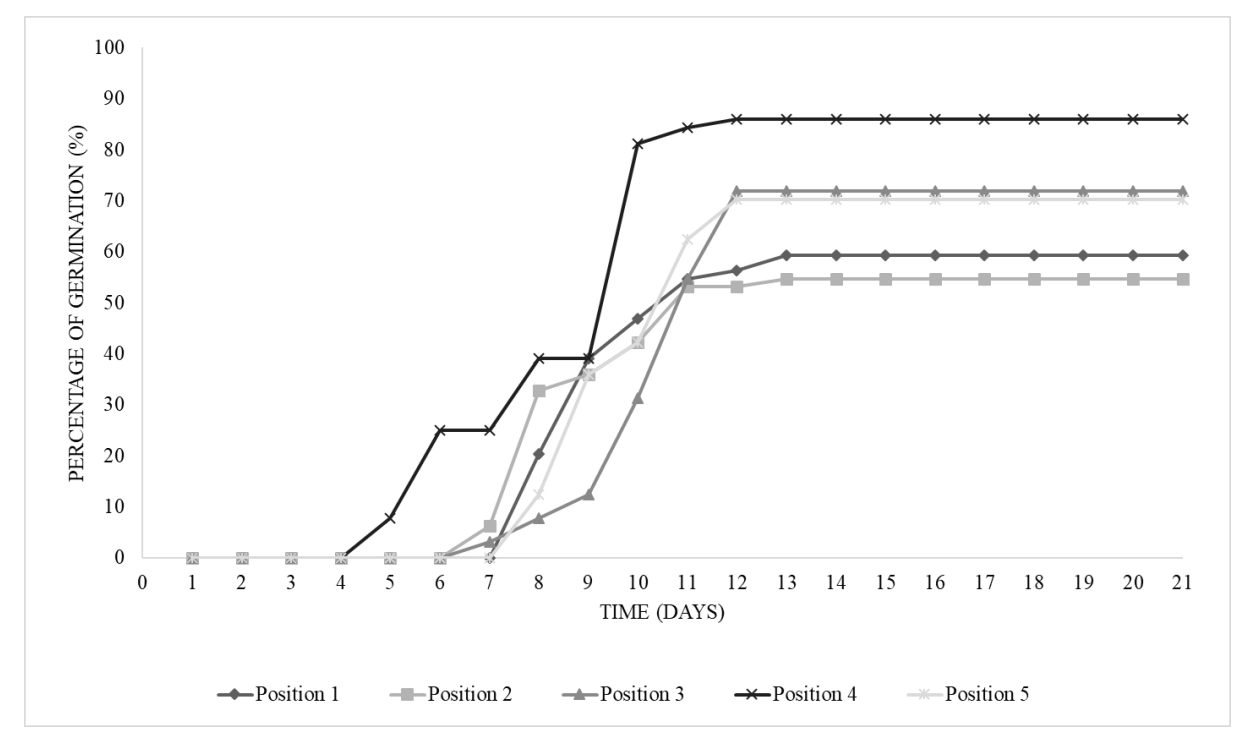

Figure 2. Percentage of germination as a function of time (days) of Caesalpinia pulcherrima in relation to the position of the seed in the fruit.

In the results of the proteins reserve (Table 2) it can be seen that the range of albumin found was 157.26 to $189.97 \mathrm{mg} \mathrm{g}^{-1} \mathrm{DM}$, and the P3, P4 and P5 presented the best values differing from $\mathrm{P} 1$ and $\mathrm{P} 2$, which presented the lowest results. The globulin fraction ranged from 18.47 to $29.19 \mathrm{mg} \mathrm{g}^{-1} \mathrm{DM}$, and the P3 had the highest concentration and differs only from P1 and P2. For prolamine, there was no statistical difference between the results, where they ranged from 20.99 to $24.62 \mathrm{mg}$ $\mathrm{g}^{-1}$ DM. For glutelin, it was observed that $\mathrm{P} 4$ had the highest value of $37.75 \mathrm{mg} \mathrm{g}^{-1} \mathrm{DM}$, differing from all other treatments. 
Table 2. Albumin, Globulin, Prolamine and Glutelin in seeds of C. pulcherrima in relation to the position in the fruit, and correlation with Germination Percentage (PG), Germination Speed Index (GSI), Average Germination Time (AGT) and Time to germination of $50 \%$ of the population $\left(\mathrm{T}_{50}\right)$.

\begin{tabular}{|c|c|c|c|c|}
\hline \multirow{2}{*}{ Position } & Albumin & Globulin & Prolamine & Glutelin \\
\hline & \multicolumn{4}{|c|}{------------------- $\mathrm{mg} \mathrm{g}^{-1} \mathrm{DM}$------------------ } \\
\hline P1 - distal & $157.26 \mathrm{~b}$ & $18.70 \mathrm{~b}$ & 24,62 a & $29.58 \mathrm{~b}$ \\
\hline P2 - distal-median & $165.00 \mathrm{~b}$ & $18.47 \mathrm{~b}$ & $23.40 \mathrm{a}$ & $30.10 \mathrm{~b}$ \\
\hline P3 - mediana & $178.17 \mathrm{a}$ & $29.19 \mathrm{a}$ & $22.87 \mathrm{a}$ & $26.03 \mathrm{~b}$ \\
\hline P4 - proximal-median & $189.97 \mathrm{a}$ & $29.09 \mathrm{a}$ & $21.78 \mathrm{a}$ & $37.75 \mathrm{a}$ \\
\hline P5 - proximal & $184.86 \mathrm{a}$ & 27.99 a & $20.99 \mathrm{a}$ & $28.85 \mathrm{~b}$ \\
\hline $\operatorname{CVC}(5 \%)$ & 13.05 & 5.76 & 4.40 & 4.95 \\
\hline CV $(\%)$ & 2.77 & 8.68 & 7.19 & 6.05 \\
\hline $\mathrm{F}$ & $23.75^{* *}$ & $20.42 * *$ & $2.23^{\mathrm{ns}}$ & $16.87 * *$ \\
\hline \multicolumn{5}{|l|}{ Correlation Coefficient (r) } \\
\hline PG (\%) & $+0.9025^{*}$ & $+0.8689^{*}$ & $-0.7085^{\mathrm{ns}}$ & $+0.5958^{\mathrm{ns}}$ \\
\hline GSI & $+0.7542^{\mathrm{ns}}$ & $+0.6119^{\mathrm{ns}}$ & $-0.5402^{\mathrm{ns}}$ & $+0.8651^{*}$ \\
\hline AGT & $-0.0304^{\mathrm{ns}}$ & $+0.3062^{\mathrm{ns}}$ & $-0.0013^{\mathrm{ns}}$ & $-0.8738^{*}$ \\
\hline $\mathrm{T}_{50}$ & $-0.7371^{\mathrm{ns}}$ & $-0.8308^{\mathrm{ns}}$ & $+0.5377^{\mathrm{ns}}$ & $-0.0371^{\mathrm{ns}}$ \\
\hline
\end{tabular}

Averages followed by the same do not differ at the level of $5 \%$ of significance by the Tukey test. ns - not significant; * - significant at $5 \%$; ** - significant at $1 \%$. $\mathrm{mg} \mathrm{g}^{-1} \mathrm{DM}$ - milligram per gram of dry mass

According to Silva et al. (2001), the range found in the protein contents are variable for the legume family, varying according to the species, cultivar and cultivation system, thus differing in their functional properties and nutritional quality. These authors working with Cicer pyramidalis found values of globulin (41.79\%), albumin $(16.18 \%)$, glutein $(9.99 \%)$ and small percentage in prolamines $(0.48 \%)$. Dantas et al. (2008) observed in Caesalpinia pyramidalis average levels of albumin, globulin, prolamine and gluteline of 179.00, 25.00, 19.00 and $37 \mathrm{mg} \mathrm{g}^{-1} \mathrm{DM}$ respectively, being these values within those found in the present study.

Rosa et al. (2000) in a study with seeds of Lathyrus sativus (Fabaceae), observed that the globulins make up a vast majority in the seed proteins, and also affirm that they are known to be the largest component in reserve tissues in legume cotyledons, however in the present study the highest levels in all treatments were observed with albumin.

The influence on protein concentrations (Table 2), in function to the position that each seed occupies in the fruit can be explained by Mondo and Cicero (2005), whose says that the quantity of reserves is a reflection of the order of fertilization of the eggs, since the first ones to be fertilized have a longer time of obtaining the photoassimilates of the mother plant. With this to depend on the location of the seed in the fruit these can be formed first in a certain region of the same, presented higher protein content. In the present study, the most distant positions of the peduncle (P1 and P2) presented the lowest results, and the closest ones, the highest values, corroborating with the cited one.

According to Marcos Filho (2005), these amounts of reserve proteins may be closely related to the seed germination power, and this is evident when observing the Pearson correlation coefficients described in Table 2. It is noted that the fractions albumins and globulins correlated positively with the percentage of germination $(+0.9025$ and +0.8689 , respectively). Also, as can be observed in Table 2, the glutelin fraction correlated positively with the germination speed index $(+0.8651)$ and negatively with the average germination time $(-0.8738)$, that is, the higher the amount of this protein, the greater the speed of germination of a seed, germinating in a shorter time. Thus, P4 that presented the highest content of said reserve $\left(37.75 \mathrm{mg} \mathrm{g}^{-1}\right.$ DM) found higher GSI (0.88) and lower AGT (8.32 days) according to the results described in Table 1. 
Thus, the fact that there was a high and positive correlation between the fractions of albumin and globulin and PG, should be, because the two proteins are mainly stored in the embryo, serving as the main reserve source at the time of germination processes. The other fractions (prolamin and glutelin) were found in large proportions in the endosperm (Nonogaki et al., 2007), being essential for the germination process to continue, where these reserves have to be transported to the embryo for later emission radicle (Taiz and Zeiger, 2017).

In synthesis, position 4 presented in general the best results of vigor and reserve proteins, however, it would not be economically feasible to use only one seed in each fruit for propagation of the species. Thus, since the P3 and P5 positions showed good results, they could also be recommended for seedling production. Also, new analyzes may be essential to improve information regarding the propagation of the species.

\section{Conclusions}

There was influence of the seed position in fruit on Caesalpinia pulcherrima germination and reserve proteins contents, providing the position 4 (proximal-median) excellent results. For propagation of the species Caesalpinia pulcherrima, it is recommended the use of seeds of the median, proximal/ median and proximal position (P3, P4 and P5), that present high percentage of germination and reserve proteins.

\section{Author contribution}

P.L.F.S. ${ }^{0000-0002-1956-1030}$ : Idea of the experiment, installation of the experiment, field analysis, data collection and analysis, interpretation, preparation and writing of the article, critical review. R.M.M.C..$^{0000-0003-3421-7235}$ : Adviser of work, analysis and interpretation of data, critical review of the article, approval of the final version of the article. R.R.P. ${ }^{0000-0002-8026-7957}$ : Installation of the experiment, field analysis, data collection and analysis, interpretation, critical review.

\section{References}

ALVES, M.M.; ALVES, R.U.; ARAÚJO, L.R.; LIMA, M.L.S. Substrate in the emergence and initial growth of seedlings of Caesalpinia pulcherrima. Ciência Rural, v.47, n.3, p.1-5, 2017. DOI: https://doi.org/10.1590/0103$8478 \mathrm{cr} 20150433$

ARAÚJO NETO, J.C.; CAMARA, C.A.; FERREIRA, V.M.; LESSA, B.F.T.; OLIVEIRA, Y.M. Morphometric characterization, germination and conservation of Caesalpinia pulcherrima (L) SW. (Fabaceae: Caesalpinioidea) seeds. Semina: Ciências Agrárias. v.35, n.4, p.2287-2300, 2014. DOI: https://doi.org/10.5433/16790359.2014v35n4Suplp2287
ARAÚJO, F.S.; ALVES, M.M.; SILVA, G.Z.; BRUNO, R.L.A.; PACHECO, M. Emergência e vigor de plântulas de Caesalpinia pulcherrima em função da profundidade de semeadura. Tecnologia \& Ciência Agropecuária, v.8, n.4, p7-11, 2014.

BAWA, K.S.; BUCKLEY, D.P. Seed: ovules ratios, selective seed abortion and mating systems in Leguminosae. Monographs in Systematic Botany from the Missouri Botanical Garden, v.29, p.243-262, 1989.

BRADFORD, M.M. A rapid and sensitive method for the quantitation of microgram quantities of protein utilizing the principle of protein-dye binding.1976. Analytical Biochemistry. v.72, n.248-259, 1976. DOI: https://doi. org/10.1016/0003-2697(76)90527-3

COOLBEAR, P.; FRANCIS, A.; GRIERSON, D. The effect of low temperature pre-sowing treatment on the germination performance and membrane integrity of artificially aged tomato seeds. Journal of Experimental Botany, v.35, n.11, p.1609-1617, 1984. DOI: https://doi. org $/ 10.1093 / \mathrm{jxb} / 35.11 .1609$

DANTAS, B.F.; CORREIA, S.; MARINHO, L.B.; ARAGÃO, C.A. Alterações bioquímicas durante a embebição de sementes de catingueira (Caesalpinia pyramidalis Tul.). Revista Brasileira de Sementes. v.30, n.1, p.221-227, 2008. DOI: https://doi.org/10.1590/S010131222008000100028

FLORA DO BRASIL. Caesalpinia pulcherrima (L.) Sw. Jardim Botânico do Rio de Janeiro. Available in: $<$ http://floradobrasil.jbrj.gov.br/reflora/floradobrasil/ FB22844>. Accessed on: 10 Feb. 2019.

FREITAS, T.P.; FREITAS, T.A.S.; CAMPOS, B.M.; FONSECA, M.D.S.; MENDONÇA, A.V.R. Morfologia e caracterização da germinação em função da posição das sementes no fruto de sabiá. Scientia Plena, v.9, n.3, p.1-9, 2013.

LABOURIAU, L. G. A Germinação das sementes. Washington: Organização dos Estados Americanos, 1983. $171 \mathrm{p}$.

LEE, T.D.Y.; BAZZAZ, F.A. Regulation of fruit and seed production in an annual legume, Cassia fasciculata. Ecology, v.63, p.1363-1373, 1982. DOI: https://doi. org/10.2307/1938864

LESSA, B.F.T.; ALMEIDA, J.P.N.; PINHEIRO, C.L.; NOGUEIRA, F.C.B.; MEDEIROS FILHO, S. Germinação e crescimento de plântulas de Enterolobium contortisiliquum (vell.) morong em função da localização da semente no fruto e regimes de temperatura. Bioscience Journal, v.3, n.5, p.1474-1483, 2014. 
LORENZETTI, E.; CARVALHO, J.C.; SOUZA, A.K.P.; QUEIROZ, S.B.; BELMONTE, C.; MALAVASI, M.M. Determinação da maturidade fisiológica de Caesalpinia peltophoroides Benth. pela coloração de sementes. Scientia Agraria Paranaensis, v.17, n.2, p.231-235, 2018.

MAGUIRE, J.D. Speed of germination-aid in selection and evaluation for seedling emergence and vigor. Crop Science, v.2, n.1, p.176-177, 1962. DOI: https://doi.org/10.2135/cro psci1962.0011183X000200020033x

MARCOS FILHO, J. Fisiologia de sementes de plantas cultivadas. São Paulo: Editora FEALQ-USP,2005. 495 pp.

MENA-ALI, J.I.; ROCHA, O.J. Effect of ovule position within the pod on the probability of seed production in Bauhinia ungulata (Fabaceae). Annals of Botany, v.95, n.3, p.449-455, 2005. DOI: https://doi.org/10.1093/aob/ mci044

MENDONÇA, A.V.R.; FREITAS, T.A.S.; SOUZA, L.S.; FONSECA, M.D.S.; SOUZA, J.S. Morphology of fruit and seed and germination on Poincianella pyramidalis (Tul.) L. P. Queiroz, comb. Nov. Ciência Florestal, v.26, n.2, p.375387, 2016. DOI: https://doi.org/10.5902/1980509822738

MONDO, V.H.V.; CICERO, S.M. Análise de imagens na avaliação da qualidade de sementes de milho localizadas em diferentes posições na espiga. Revista Brasileira de Sementes, v.27,p.9-18, 2005. DOI: https://doi.org/10.1590/ S0101-31222005000100002

MOTERIYA, P.; CHANDA, S. Synthesis and characterization of silver nanoparticles using Caesalpinia pulcherrima flower extract and assessment of their in vitro antimicrobial, antioxidant, cytotoxic, and genotoxic activities. Artificial Cells, Nanomedicine, and Biotechnology, v.45, n.8, p.1556-1567, 2016. DOI: https:// doi.org/10.1080/21691401.2016.1261871

NOGUEIRA, N.W.; MARTINS, H.V.G.; BATISTA, D.S.; RIBEIRO, M.C.C. Grau de dormência das sementes de jucá em função da posição na vagem. 2010. Revista Verde de Agroecologia e Desenvolvimento Sustentável, v.5, n.1, p.39-42, 2010.

NONOGAKI, H.; CHEN, F.; BRADFORD, K.J. Mechanisms and genes involved in germination sensu stricto. Annual Plant Reviews, v.27, p.264-304, 2007. DOI: https://doi.org/10.1002/9780470988848.ch11

OLIVEIRA, L.M.; BRUNO, R.L.A.; GONÇALVES, E.P.; LIMA JÚNIOR, A.R. Tratamentos pré-germinativos em sementes de Caesalpinia pulcherrima (L.) Sw.Leguminosae. Revista Caatinga, v.23, n.1, p.71-76, 2010.
OLIVEIRA, O.F.; MORAIS, P.L.D. Morais. Influência da posição da semente (no fruto) na germinação e no desenvolvimento vegetativo inicial de leucena (Leucaena leucocephala (lam.) Dewit) e algarobeira (Prosopisjuliflora (sw.) Dc.). Revista Caatinga, v.10, n.1, p.55-62, 1997.

PAISE, G. Aborto seletivo e predação de sementes no feijãoda-praia Sophora tomentosa (Fabaceae). In: Machado, G.; Prado, P. I. K. y Oliveira, A. A. (ed). Curso de campo "Ecologia da Mata Atlântica". São Paulo: Editora USP. p.05-10.

ROCHA, R.G.L.; RIBEIRO, M.C.C.; SILVA, F.D.B. Desenvolvimento inicial do feijão guandu em diferentes profundidades e posições da semente na vagem. Agropecuária Científica no Semiárido, v.13, n.4, p.297301, 2017.

ROSA, M.J., FERREIRA, R.B.; TEIXEIRA, A.R. Storage proteins from Lathyrussativus seeds. Journal of Agricultural and Food Chemistry, v.48, p.5432-5439, 2000. DOI: https://doi.org/10.1021/jf000447r

SANTOS, G.O.; HERNANDEZ, F.B.T. Uso do solo e monitoramento dos recursos hídricos no córrego do Ipê, Ilha Solteira, SP. Revista Brasileira de Engenharia Agrícola e Ambiental, v.17, n.1, p.60-68, 2013. DOI: http://dx.doi. org/10.1590/S1415-43662013000100009

SANTOS, P.L.F.; CASTILHO, R.M.M. Floriferous herbaceous and substrates for use on extensive green roofs. Ornamental Horticulture, v.24, n.3, p.261-268, $2018 \mathrm{a}$. DOI: http://dx.doi.org/10.14295/oh.v24i3.1251

SANTOS, P.L.F.; CASTILHO, R.M.M. Germination and development of ornamental sunflower seedlings in substrates. Ornamental Horticulture, v.24, n.4, p.303310, 2018b. DOI: https://doi.org/10.14295/oh.v24i4.1152

SILVA, J.P.N.; CENTENO, D.C.; FIGUEIREDORIBEIRO, R.C.L.; BARBEDO, C.J. Maturation of seeds of Poincianella pluviosa (Caesalpinoideae). Journal of Seed Science, v.37, n.2, p. 131-138, 2015. DOI: http://dx.doi. org/10.1590/2317-1545v37n2146864

SILVA, M.A.; NEVES, V.A.; LOURENÇO, E.J. Frações protéicas e globulina principal de grão-de-bico (Cicerarietinum L.), cv IAC-Marrocos. Alimentos e Nutrição, v.12, n.1, p.131-149, 2001.

SOUZA, N.A.; SILVA, K.B.; OLIVEIRA, A.N.P.; AGUIAR, V.A.; PINTO, M.S.C. Emergência e crescimento inicial de plântulas de Caesalpinia pulcherrima (L.) Swartzsob diferentes substratos. Revista AGROTEC, v.35, n.1, 106-112, 2014.

TAIZ, L.; ZEIGER, E. Fisiologia e desenvolvimento vegetal. Porto Alegre: Editora Artmed. 2017. 858 pp. 